\title{
UNIVERSITIES' POLICY OF SUPPORTING STUDENTS IN ACADEMICALLY DIVERSE ENVIRONMENT
}

\author{
F. R. Zagirova, I. D. Froumin \\ National Research University «Higher School of Economics» \\ 16 Potapovsky lane, b. 10, Moscow, 101000, Russian Federation; \\ fzagirova@hse.ru
}

\begin{abstract}
The aim of this work is to review and analyse the support and development practices for students based on their educational background and academic performance. The increasingly widespread concept of a responsible university involves an opportunity to close or make smaller the gap between academically diversified students. Thus, the purpose is to systematise the practice of working with both low and high-achieving students and assess the possibilities for improving the quality and effectiveness of this work. The analysis regarding existing practices of Russian and international universities is based on the literature review of more than 1600 sources. The review provides identification, comparison and systematisation of common practices used by departments and universities rather than individual teachers. A classification of practices at the stages of identifying, developing and evaluating low and high-achieving students is proposed. Recommendations are formulated for expanding the support and development of students under the conditions of academic diversity and for improving the quality and effectiveness of the educational process.

Keywords: academic diversity, student support, development practices, high-achieving students, low-achieving students, international experience, Russian experience

For citation: Zagirova F. R., Froumin I. D. Universities' Policy of Supporting Students in Academically Diverse Environment. University Management: Practice and Analysis. 2019; 23(5): 31-42. DOI: 10.15826/umpa.2019.05.039
\end{abstract}

\section{Introduction}

The increasingly diverse role of universities in recent decades has led to terms such as «conscientious» or «responsible» appearing more often in the speeches of researchers and officials from leading Russian and international universities. Such responsibility involves not only a symbiosis of the main missions or functions of the university, i.e. education, research and engagement to the satisfaction of local needs, but also a conscious restructuring of the activities of the entire university aimed at bringing maximum benefit to society. University thus among other institutions becomes responsible for society, research and the labour market. However, this responsibility certainly does not exclude the university's basic function of educating younger generation; it now has a new component: a responsible university, should be aware of what students are learning in it, and also become more conscious of its interactions with them.

The massification of higher education causes many universities to encounter the phenomenon of academic diversity $[1,2]$, implying the range of differences in student academic preparation prior to entering the university and their subsequent academic performance. However, unlike other types of student diversity, this phenomenon is not well researched by modern scholars. For example, problems related to ethnic [3, 4] and socio-economic inequality $[1,4,5,6]$ and issues of women in higher education (gender inequality, [3]) are more frequently covered in academic discussions. Relatively often in research, academic diversity is associated with interactions within academic groups, both at basic school level and in higher education. The relationship between the frequency of interaction between teachers and students and academic achievements of the latter is quite well-understood [7]. In turn, academic diversity of the group is associated with the so-called peer-effect which suggests that frequent social interaction between students in such groups influence their learning outcomes; at the same time, not all influence is necessarily positive [8]. However, despite the evidence of academic diversity, its relationship with the functioning of educational institutions remains poorly covered in literature.

In Russia, the particular relevance of studying academic diversity, as well as the practices emerging at university under conditions of such diversity, is important for several reasons. As a consequence of current higher education financing policy, Russian 
universities aim at targeting the most talented applicants ${ }^{1}$. However, most Russian universities operate under conditions of high level of students' academic diversity what can be explained by different levels of academic preparation of students admitted in different university's schools, and by academic difference among publicly-funded and fee-paying students ${ }^{2}$. The uneven distribution of admission quotas in the areas of training (namely, the distribution of state-funded admission quotas for disciplines with low admission criteria) and the policy of merging universities with different levels of academic requirements for applicants $^{3}$, can also cause high level of students' diversity at Russian universities.

The public policy factors that reinforce diversity are superimposed by demographic factors. Due to demographic trends showing that the number of people aged 17-21 years will continue to increase until $2034^{4}$, the number and diversity of university attendees is also expected to grow. With current policies and mechanisms of control a sharp increase in the number of universities is very unlikely. At the same time, for many universities, expanding student admissions is one of the few and fairly obvious means of increasing their resource base. This means that existing universities will accept more students, which adds to the growing challenge of dealing with academically diversified student population.

At the same time, another element of state policy also ties universities to resources, this time from the point of view of reducing student dropouts. If a certain dropout rate is exceeded, a university runs the risk of having its state funding reduced ${ }^{5}$. This encourages universities to implement instruments for monitoring failure, as well as developing various practices for the support and development of underprepared students.

Thus, the situation of academic diversity complicates the management of the university. In case

${ }^{1}$ An opportunity to get a higher level of financing for a higher average entrance exam score, as documented in Appendix 9 of the Order of the Ministry of Education and Science of the Russian Federation of July 20, 2016 № 884.

${ }^{2}$ Zagirova F., Romanenko K., Makaryeva A. «And we are so different». Academic heterogeneity of students: analysis, perceptions, practices. Modern Education Analytics, 2019, № 4 (25). (In Russ.).

${ }^{3}$ Ibid.

${ }^{4}$ Information from the table «Populations by one-year olds» of the Federal State Statistics Service, available at: http: / /www.gks.ru/ wps/wcm/connect/rosstat_main/rosstat/ru/statistics/population/demography/ (accessed: 12.08.2019).

${ }^{5}$ For public universities - Section 46 of the Decree of the Government of the Russian Federation of June 26, 2015, No. 640 , available at: http://www.consultant.ru/cons/cgi/online.cgi?req $=$ doc $\&$ base $=$ LAW \&n $=312531 \&$ fld $=134 \& d \mathrm{st}=1000000001,0 \& \mathrm{r}$ $\mathrm{nd}=0.26129928182927387 \# 037642312661538857$ (accessed: 12.08.2019). The activities of universities of regional importance are regulated by regional legislation. of low-achieving students, universities are typically faced with the task of «pulling up» or developing such students. At the same time, high-achieving students still require to be taken care of; thus, universities are also faced with the task of maintaining these students' interest in learning and developing their competencies. Additionally, many universities see their better-achieving students as candidates to a role of potential and as representatives maintaining the image of the university outside as a place of quality education. Under such conditions, the diversity of academic preparation and performance underlies the need to use a wide range of practices to support and develop students.

In the context of a responsible university, it is important to expand the boundaries of existing research on what is happening inside one cell of the university - the academic group - to what happens at the university, in general. A responsible university must be responsive to the needs of the least prepared and simultaneously satisfy the requirements of the most prepared students. Both at the academic group level and top management level, the dedicated work of teachers and administrators is required to maximize students' educational results.

However, one cannot state that even the most selective universities escape the academic diversity. Under pressure from public expectations and educational policies, these universities usually selecting the most prepared and talented students, are compelled to take actions leading to an the growth of academic diversity. World leading universities are increasingly creating special programmes to open the doors of the university to students from disadvantaged backgrounds, which also implies lower academic requirements ${ }^{6}$. Accordingly, where such conditions lead to academic diversity, there should be practices to support and develop different groups of students.

This article focuses on the practices and instruments that would be referred to as macro-practices in the field of social work. In social work, macropractice implies established activities outside the interaction of a social worker with an individual client or a small group of clients. Such practices are distinguished by the use of indirect and organisational leverage in order to improve the state of large population groups. Thus, if social worker and its interaction with clients are replaced with a teacher and teaching groups of students in degree-based educational programme (EP), macro-practices in the context of the

${ }^{6}$ According to the latest news from BBC News, Oxford university promises to provide 250 places with full coverage of education and living expenses for graduates of public schools from disadvantaged families by 2023, available at: https://www.bbc.com/news/education-48336059 (accessed: 12.08.2019). 
current paper are the practices organised at the level of departments or the whole university, aimed at the support and developing certain groups of students. The practices discussed here do not include studentteacher interactions within the EP.

In order to analyse practices for supporting and developing students in conditions of academic diversity, let us consider them in the context of different groups of students, as is often done, for example, in literature on ethnic or racial diversity, when researchers focus their attention on students belonging to certain groups. Thus, for example, many studies have been carried out on the factors leading to academic success of Latin American, Asian and African American students and a comparison of these ethnic groups with each other (for example, in [9]). The instruments and practices used to improve conditions and learning outcomes also fall readily into the pattern of working with certain ethnic or social groups (for example, in [10]). On an analogous basis, the present article also focuses on practices aimed at working with different groups of students, which can be distinguished by the academic criterion: namely, students with high and low levels of achievement and preparation (hereinafter, they will be referred to as high and low achieving students, implying the level of preparation as well).

Then, the aim of this work is to systematise the practices of handling high and low achieving students, as well as to assess the possibilities for improving the quality and effectiveness of this work. For this, both Russian and international practices handling academically diversified students are considered. The search for current practices was limited by the level of undergraduate degrees and full-time form of education.

The article consists of five parts. In the first part, methodology of this study is described. The second part provides information on international practices handling academically diverse students. The third part is devoted to analysis of existing practices in Russian universities, while the fourth one provides a systematisation of all discovered practices. The final part provides conclusions and recommendations on possible areas for the development of Russian practices.

\section{Research methodology}

In order to review Russian and international student practices, a large pool of articles and reports available through the HSE library service was analysed. This approach to the study of practices was first widely adopted in evidence-based medicine and later started to be applied in education. Here, the methods and characteristics used for the review should be quite clear and determined from the very beginning so that the results can be traced and repeated.

For this article, the search for literature sources was carried out using the EBSCO Discovery Service available through the HSE electronic library. In order to identify works about Russian institutes of higher education written in Russian, a search was performed using the e-Library electronic resource. The search was limited to 2009-2019, since the purpose of the study is to systematise contemporary practices for the students with different levels of preparation.

The selection of articles was carried out in stages. At the first stage, the titles and abstracts of the papers were checked against the further content analysis of the remaining articles. The review excluded articles that:

- were beyond undergraduate degrees

- were related to distance education

- were related to an analysis of educational policies

- were focused on practices within the academic group, i.e. on interaction between teachers and students

- studied the psychological and pedagogical features of students

- were related to the physical education and health of students

- were written in neither Russian nor English

- were primarily concerned with the practice of working with international students (excluded due to the specificity of this issue)

As keywords for searching in the titles and abstracts of articles through the EBSCO Discovery Service, the following were used: «underprepared students», «talented students», «gifted students», «advanced students» in pairs with words such as «programme», «practice», «service», «support» and «course». A filter was also set to search for related words and relevant topics. A total of 362 and 162 articles were found regarding high and low-achieving students, respectively. After applying the selection criteria, two sets of 20 and 67 articles remained on international practices of working with the first and the second group of students, respectively. An additional 6 articles were found in two languages about practical work with high acieving students in Russia.

In Russian, the search was initially conducted in the e-Library database using similar combinations of Russian translations for the mentioned above terms. However, such a search yielded no results, so it was limited to phrases related to students. A total of 820 articles on high-achieving students and 335 on low-achieving students were found. After analysing the titles and abstracts of the articles that fit the topic of the study, only 47 and 15 works were left 
regarding work practices in the first and the second group, respectively.

Due to the low quality of academic literature on the practices used by Russian universities, these data were supplemented by information obtained by the author earlier during a series of interviews with top and middle-level managers of Russian universities. Semi-structured interviews were conducted during December 2018 - April 2019. Initially, it was planned to conduct interviews only with the vice-rectors responsible for the educational activities, however some vice-rectors recommended to contact with head of the structural unit, also involved in organizing educational activities. Thus, interviews with 17 vice-rectors and 2 senior administrators involved in organizing educational activities in universities from 14 regions are included in this work. The range of the unified state exam (USE) scores for the respondents whose tuition was fully paid by the government was between 55 and 92 points; the full-time student enrolment in 2017 at those universities was from 600 to 21,000 .

Initially, respondents were asked to attend an interview in person or in video format, however, some administrators offered their own communication options. As a result, the interviews were conducted as follows: 5 -in person, 11 - using video communications provided by Skype and WhatsApp, 1 - through e-mail correspondence, 1 -through correspondence in WhatsApp, and 1 - via telephone conversation. All oral interviews, with the exception of one, were recorded with voice recorder and transcribed with the permission of the respondents. According to one interview, the recording of which was interrupted at the very beginning, an abstract was compiled immediately after the end of the conversation.

\section{Practices of working with academically diversified students: international experience}

In global practice, there are several approaches based on different values of educational policies to classify certain groups of students. For example, Scandinavian countries traditionally adhere to the principle of equality, promoting equal educational opportunities for everyone, both at the secondary and higher education levels. No talent preferences are applied and methods for identifying gifted students and their further development are little used. In contrast, the United States, China, as well as most Western European countries, tend to rely on the principles of meritocracy. However, since the massification of higher education does not provide admission of high academic quality in all universities, groups of prepared and unprepared students are distinguished and accordingly, various instruments for working with them are offered. Therefore, the practices described below are more common in the latter countries, although they are also echoed in other contexts.

To begin, let us consider the practices related to the admission, support and development of highachieving students. Probably, the most popular way to work with high-achieving students abroad is presented by the so-called Honours Programs. For example, in the United States, about 800 colleges and universities are members of the National Collegiate Honors Council ${ }^{7}$, although such programmes have been implemented in European countries relatively recently. The practice of their implementation varies not only from country to country, but even within the same university: the target group of students (bachelors, masters or graduate students), the programme content (interdisciplinary or disciplinary, aimed at deepening or expanding knowledge), admission criteria, interrelation with chosen EP, purpose, programme confirmation form and others. However, the main idea remains the same; to provide these students with more challenging education in order to ensure their engagement and development.

Some American universities operate several academic excellence programmes; sometimes separate colleges are created to attract talented students. One such example is the University of Ohio, where at least five academic excellence programmes are administered and one college is formed. At least one programme / college is designed for students of multiple disciplines and interests, while others are aimed at working with students having particular areas of interest $^{8}$. In Patton College of Education alone, students are provided with two academic excellence programmes ${ }^{9}$ differing in goals: one is designed to support and increase interest in the teaching profession, while the other is aimed at improving students' skills in implementing specific projects in the field of education.

Another example is Hunter College, one of the largest colleges in City University of New York. At least three programmes of academic excellence are additionally implemented here. One of these, the Catalyst Scholarship Programme ${ }^{10}$ is designed specifically for students from families with low socioeconomic status (SES), demonstrating high educational results and studying in STEM-disciplines. The

\footnotetext{
${ }^{7}$ Available at: https://www.nchchonors.org/ (accessed: 05.08.2019).

${ }^{8}$ Available at: https://www.ohio.edu/scholars/ (accessed: 05.08.2019).

${ }^{9}$ Available at: https://www.ohio.edu/education/academic-programs/honors-programs/index. cfm (accessed: 05.08.2019).

${ }^{10}$ Available at: http://www.hunter.cuny.edu/catalyst/programgoals (accessed: 05.08.2019).
} 
programme includes faculty mentoring of undergraduate students. Students must participate in the general geosciences course and develop their own academic success plan. The programme covers most of the costs of education so that students can devote their time to study rather than finding a job. The choice of the programme components was made for a reason: it was developed based on research into the effectiveness of certain practices and instruments for interacting with students [11].

The University of Auckland in New Zealand also offers academic excellence programmes in various fields of study. An honours degree is awarded for an additional successful year of study on the undergraduate programme; subject to high learning outcomes; this gives students the right to continue on to a Master's programme or even doctoral study ${ }^{11}$. Only those who have studied well in the main undergraduate programme can project their study on the honours track.

In the same university, approaches for working with high-achieving students include the possibility of awarding internships or involving students in teachers' research projects in summer, with a stipend awarded for participation [12]. In Australia, high achieving students are also involved in research. For example, the Talented Students Programme of the University of New South Wales in Sydney ${ }^{12}$ sets the involvement of talented students in research as its goal. Students are invited either at the very beginning of training on the basis of admission points or based on current performance. The distinctive point in the implementation of this programme is that the first year of participation implies no academic or research work, - only meetings with senior students participating in the same programme and introduction to university research centres and projects during special presentations. Then, in the second year, students choose a research project of interest and start working in it.

Sometimes universities cooperate to create development programmes for high-achieving students. In this way, the Copenhagen Business School (Denmark), the Chinese University of Hong Kong and the University of Northern California have teamed up to implement the programme for talented undergraduate students called Globe, which includes semester-long studies at each university ${ }^{13}$. Each university selects 18 talented students, forming a group of 54

${ }^{11}$ Available at: e.g. https: // www.auckland.ac.nz/en/study/studyoptions/find-a-study-option/bachelor-of-science-honours-bschons.html (accessed: 05.08.2019).

${ }^{12}$ Available at: https://www.science.unsw.edu.au/future-students/ talented-students- program (accessed: 05.08.2019).

${ }^{13}$ Globe program, available at: https://www.cbs.dk/en/study/bachelor/bsc -in-international-business / globe (accessed: 05.08.2019). students studying together for three semesters. This programme is designed for second-year business major bachelor's students.

Support for the low-achieving students in the United States and Australia is also critically important. This is primarily due to the high dropout rate of students themselves from the post-secondary education system. By helping underprepared students, universities seek to retain them and provide opportunities for the successful completion of educational programmes.

A common practice of «pulling up» students to the right level is by providing remedial or developmental education. This usually means having remedial courses for students who suffer from insufficient preparedness for higher education. It can have several forms: the more common option implies students to take developmental courses prior to their EP studies. According to the second option, students are given the opportunity to catch up with their peers while taking regular classes. The remedial courses are usually for fee and provide no educational credits for students.

There is no conclusive evidence of the effectiveness of such courses. On one hand, a number of studies indicate that students choosing the remedial courses demonstrate better results in core courses than those who do not take this opportunity [13]. On the other hand, a number of works indicate such courses to constitute an ineffective instrument for teaching low-achieving students: less than half of those entering corrective courses are able to graduate on time [14]. At the same time, it is also worth noting that this practice has a different effect on students with different levels of lagging behind. Thus, students with a small knowledge gap cope with developmental courses quite well, while significantly underprepared students are more likely to fail [15]. The ambiguous effectiveness of this practice makes politicians and higher education managers look for other ways to solve the problems of low-achieving students and resort to other practices of working with them.

As an alternative to compulsory remedial courses, compulsory counselling for all students who may need it is provided, for example, by the U.S. state of Florida [16]. At the University of Southern Indiana, at-risk students studying STEM programmes are also provided with intrusive advising programme in parallel with corrective courses for the purpose of providing academic support [17]. Fifteen students to one consultant are allocated at the university. For each student from the at-risk group, 5 compulsory individual meetings are held where the student's educational schedule is built, his or her educational progress is discussed and a strategy for preparing for tests and exams is developed. 
In general, counselling formats may vary. In some cases, counselling is held tête-à-tête, while in other cases, it takes the form of a meeting of an instructor with a group of students. Meetings are not limited to discussing students' academic performance but are also devoted to learning skills and consideration of the cognitive process and problems facing students within the learning process. In the United States, counselling practices prove to be an effective means for retaining students at the university and improving their academic performance; moreover, they represent a financially affordable method of supporting students [18].

In the United States, the practice of supporting low-achieving students is gaining popularity in the form of learning communities. For low-achieving students, this often means that universities try to distribute them within the framework of remedial education so that they intersect at a greater number of meetings and classes [19]; that is, they form what in the Russian context is understood as study groups. The difference is that these groups often mix students with different majors. Studies also confirm that these groups help improve students' academic performance and their sense of belonging to the university community [20].

The combination of the above practices for working with low-achieving students (remedial courses, academic counselling, learning communities, other additional seminars) is a common practice in the United States. However, some universities go even further. For example, as part of its EASE programme for students of the School of Biological Sciences, the University of California ${ }^{14}$ also gives students participated at the programme a priority to enrol in the next level courses in biology and chemistry [20].

Bridge programmes constitute another way for supporting underprepared students. Unlike corrective courses, these programmes are most frequently implemented in the interaction of regional universities and colleges. In bringing students' competencies to the required level, such programmes are designed to help students adapt to the requirements and the environment of the educational institution where the transition takes place. Such programmes, for example, are implemented in the University of Toronto (Canada) ${ }^{15}$ and in the Auburn University (Montgomery, United States) ${ }^{16}$. These partnership programmes are also being implemented in Kansas institutions: in order to ensure student success, Pittsburgh State University has partnered with Fort Scott Community College [21].

\footnotetext{
${ }^{14}$ Available at: https://www.bio.uci.edu/easeprogram/ (accessed: 05.08.2019).

${ }^{15}$ Available at: https://wdw.utoronto.ca/academic-bridging (accessed: 05.08.2019).

${ }^{16}$ Available at: http://www.aum.edu/admissions/admissions-programs/bridge-program (accessed: 05.08.2019).
}

In addition to the above practices, a number of other approaches are taken. For example, career counselling for underprepared students is sometimes viewed as an effective instrument for increasing academic performance and retention: determining students' career path is believed to increase their motivation for learning and desire to obtain the corresponding educational qualifications [22]. Project-based learning is also applied to allow low-achieving students catch up and develop the necessary skills in motivating them to put theory into practice. For example, in South Africa, low-achieving students are involved in real-life projects to solve the problems for the local community [23]. Another tool used by American universities involves the senior student mentorship of the freshmen who have low level of preparation. This practice has demonstrated a positive effect at Louisiana universities, where senior students acted as mentors of students in remedial reading classes ${ }^{17}$ [24].

An important aspect of helping underprepared students includes the teacher professional development. There are special teams of professionals who train instructors and teachers to work with lowachieving students [25]. In Texas, the Catch The Next ${ }^{18}$ programme is being implemented in order to help local colleges and universities (e. g., University of Texas at Austin, Colleges in the Alamo District and South Texas College) to empower faculty, staff, and institutions to increase the educational attainment of Latinos and other underserved communities in order to close the achievement gap.

The analysis of the practices of working with high and low-achieving students, showed that in many cases both practices include additional mentoring and counselling by teachers. Indeed, according to research, the presence of an effective mentor often appears as a stimulating factor in academic progress. The practice of mentoring helps students gain access to the academic and other resources of the university and adapt to the university culture (for example, [26]).

The peer-effect is also used when working with both high and low-achieving students. Undergraduate mentorship is a fairly common practice. Special programmes (near-peer tutoring) are organised in medical universities in the United States with senior students helping freshmen. Such programmes are demonstrated to cause the greatest effect on the less achieving group of students (for example, [27]), yet the effect for high achievers is also often positive. In other cases,

\footnotetext{
${ }^{17}$ Available at: https://www.lsu.edu/eng/current/academic-support/ peer-mentors. php and (accessed: 05.08.2019). https://firstyear.louisiana. edu/get-involved/peer-mentor-program (accessed: 05.08.2019).

${ }^{18}$ Available at: https://www.catchthenext.org/about-us/our-program/ (accessed: 05.08.2019)
} 
the peer-effect is used in assessing the tasks of classmates by students themselves. A calibrated essay peerreview can serve as an example with its platform created by the University of California, Los Angeles. In this program, teachers train students to evaluate essays based on the given criteria; after that, students evaluate work of their classmates. As the researchers note, such practice leads to a narrowing of the gap between the low and high achievers [28].

\section{Working with academically diverse students: Russian experience}

The analysed literature indicates that the highachieving or talented students are receiving much more attention at Russian universities. According to the results of the interview with university administrators, the authors came to a similar conclusion. This chapter of the article is based on knowledge obtained not only from the analysis of literature and information from the websites of universities, but also from the interviews conducted by one of the authors.

While working with high-achieving students, Russian universities use a wide range of practices, relying on the best practices of the Soviet system combined with new opportunities and experience of foreign countries. Thus, high-achieving students are incentivized financially: this includes not only traditional merit academic scholarships (MAS) approved by the regulatory documents, but also the possibility of students' priority participation in academic mobility, guaranteed room at a university dormitory (Plekhanov Russian State University of Economics, Russian Technological University MIREA, Financial University), priorities in grant support for academic and scholarly research, and tuition discounts for students who pay tuition (HSE, Moscow State Pedagogical University, Ural Federal University).

The involvement of students in research is considered by administrators and teachers as one of the instruments for the development and support of high achievers [29]. With great certainty, the latter is argued to be the main instrument for motivating highly achieving students in Russian higher education. In most cases, research activity means an additional extracurricular workload for students. Students are attracted through various forms. The simplest are the organisation of research study groups in the departments or the involvement of students in grant research under the guidance of teachers. There are some other, more complex research associations: student design bureaus (the MPEI experience is described in article [30]) student research societies, etc.
Following the practice of Western universities, Russian universities are implementing programmes of academic excellence. This practice is still in its infancy and is quite varied in its nature. At some universities, separate units or colleges are created for this purpose, for example, in Far Eastern Federal University and the University of Tyumen, while the Siberian Federal University ${ }^{19}$ is even a member of the abovementioned American national collegial council for academic excellence. At other universities, programmes are implemented within individual faculties or study areas (Kazan Federal University, Siberian State Medical University, Kazan State Medical University). The form of implementation of such programmes also varies greatly, e.g.:

-the strongest applicants are selected in a separate group and their academic program curriculum is modified (Kazan State Medical University);

-programmes of academic excellence exist in the form of degree-based educational programs which are advertised to the most talented and motivated candidates. Students apply directly to this academic programme (University of Tyumen ${ }^{20}$ );

- an additional advanced programme is offered along with the degree-based one. Students in this programme are selected based on their achievement in EP and their motivational letters (Far Eastern Federal University, Siberian State Medical University ${ }^{21}$ ). This model is the most similar to the western ones.

Summer school is another, less frequent, but still common way of working with highly achieving students. These schools are typically aimed at developing various skills and competencies (leadership, research), as well as deepening the disciplinary knowledge.

Another practice, often reflected in the structural changes of the university, is tutoring. At present, tutoring is more popular in Russia than the mentoring practiced at foreign universities. While mentoring involves cooperation in order to transfer experience and stimulate development in a particular field, tutoring is more likely to help students to determine their own educational trajectory. Tomsk State University provides a good example of a strong tutors' team ${ }^{22}$. In the Far Eastern Federal University tutoring has transformed from the practice of supporting and individualising educational trajectories of high-achieving students towards a support instrument for lowachieving students to identify their problems and develop solutions.

\footnotetext{
${ }^{19}$ Honors College of the Siberian Federal University, available at: https://elibrary.ru/item.asp?id=32829633

${ }^{20}$ Available at: https://sas.utmn.ru/ru/ (accessed: 05.08.2019).

${ }^{21}$ Available at: https://www.ssmu.ru/ru/obrazovanie/elite/ (accessed: 05.08.2019).

${ }^{22}$ Available at: https://vk.com/tutortsu (accessed: 05.08.2019).
} 
Finally, a form of assessing high achievers consists of Olympiads, intellectual games, contests and student conferences. On the one hand, such activities are often targeted at selecting the best students. On the other hand, they aim at student motivation to participate in academic and research life of the university and summarise specific results of their academic, research and / or creative activities (an example here is the Plekhanov Russian State University of Economics in [31]). Participation and victory in such competitions is important for students who want to continue their studies at graduate and postgraduate levels.

Although the peer-effect is not very often consciously used in Russia, some practices can be identified in this connection. Judging from the literature, this happens not within the educational group itself (teachers more often see the negative effects of heterogeneous groups), but rather through some other specific measures, for example, specially created scientific career centres ${ }^{23}$, where successful upperundergraduate students are invited as tutors. In other cases, a group of educational consultants from among senior students is identified; one of this group's responsibilities is to help low-achieving students [32]. Sometimes, such assistance is provided by the student councils, especially if the problem is significant, and this council is active and well functioning ${ }^{24}$. This is perhaps the only case in current Russian experience where the work is conducted with both high and lowachieving students.

It is important to mention that the work with the low-achieving students is quite limited. Literature review shows that although researchers admit the existence of the problem of low-achieving students, yet, there is no much experience in working with this category. In most cases, such experience includes remedial or extracurricular courses, which are offered at schools if there are too many underprepared students. Those courses are as a rule discipline-specific and focused on filling the gaps in basic school education [33].

There are practically no other instrument exists for solving academic problems at the level of departments and universities. Even the task of developing basic skills of intellectual activity such as taking notes lies heavy on university teachers, «it is the responsibility of the teacher to teach students how to take notes, abbreviate, highlight logical relationships, interpret material, etc.» $[34$, p.66]. At the university

\footnotetext{
${ }^{23}$ An example of such a centre is at Sechenov University, Available at: https://www.sechenov.ru/univers/structure/center/ tsentr-nauchnoykarery / (accessed: 05.08.2019).

${ }^{24}$ An example of such interaction of students is in Ural Federal University, Available at: https://vk.com/repeatitor (accessed: 05.08.2019).
}

level, it has become common practice to manage lowachieving students in manual mode.

There are some other instruments for supporting students, regardless students' academic level helping to handle student support. For example, the institute of curators, although some administrators have recognized it as not always effective. Curators act as a buffer between students and teachers and administrators. They help identify problems of low-achieving students and resolve conflicts with teachers (for example, [35]). Curators advise high-achieving students how they can best realise their potential.

The above review of Russian practices demonstrates that the work with high-achieving students is often more systemic and structural than the work with the low-achieving ones; it turns out that the instruments for identification and development of highachieving students are much more numerous and better developed. However, it must be noted that most Russian research publications in this area are descriptive and at best instructional in nature; they do not generally rely on any empirical studies of the effectiveness and efficiency of specific practices.

\section{Generalisation of practices}

A review of foreign and Russian practices allows to outline a general framework of the work with high and low-achieving students. In general, the practice of supporting these groups of students can be divided into several types as shown in Table 1. Some practices can be applied for both high-achieving and lowachieving students. In this case, the key difference lies in their specific content. In Table 1, a level is identified, where the implementation of a particular practice block is carried out. The following levels were highlighted:

- structure involves the creation of separate structural units for the practice;

- university assumes organisation and implementation of practices at the university level;

- unit involves organisation and implementation of practices at the level of faculties and institutes;

- teachers (individual level) is related to practices implemented by teachers in the framework of the EP.

Without claiming to be comprehensive, this table represents the most common practices of working with students, systematising the work conducted by universities in relation to students with different levels of preparedness and academic acheivement. Moreover, the table may allow universities eager to become responsible providers of quality education to find new currently unused niches for supporting students and maximising their academic success. 
Organisational decisions (practice blocks) targeting high and low-achieving students at different stages of interaction

\begin{tabular}{|c|c|c|}
\hline Stage & High-achieving students & Low-achieving students \\
\hline Identification & $\begin{array}{l}\text { Targeted search and retention of talented appli- } \\
\text { cants (university, unit, structure) } \\
\text { According to the results of the entrance } \\
\text { tests (USE) (unit, university) } \\
\text { Entrance in-course assessment of the readiness at the } \\
\text { beginning of the academic year (teachers) }\end{array}$ & $\begin{array}{l}\text { According to the results of entrance tests (USE) (unit, } \\
\text { university) } \\
\text { Entrance in-course assessment of the readiness at the } \\
\text { beginning of the academic year (teachers) }\end{array}$ \\
\hline Development & $\begin{array}{l}\text { Teaching practices (teachers) } \\
\text { Adaptation (individualisation) of educational pro- } \\
\text { grammes (all levels) } \\
\text { Additional programmes (unit, university, structure) } \\
\text { Mentoring (teachers, department, university) } \\
\text { Tutoring (department, university, structure) } \\
\text { Research activity (teachers, unit, university) } \\
\text { Financial support (university) } \\
\text { Structures aimed at supporting and developing stu- } \\
\text { dents (university, structure) }\end{array}$ & $\begin{array}{l}\text { Teaching practices (teachers) } \\
\text { Adaptation (individualisation) of educational pro- } \\
\text { grammes (all levels) } \\
\text { Additional programmes (unit, university) } \\
\text { Mentoring (teachers, unit, university) }\end{array}$ \\
\hline Evaluation & $\begin{array}{l}\text { Academic competitions (unit, university) } \\
\text { Other competitions (unit, university) } \\
\text { Exhibitions of student work (unit, university) }\end{array}$ & $\begin{array}{l}\text { Analysis of academic achievement at the curricular } \\
\text { courses (teachers, unit) }\end{array}$ \\
\hline
\end{tabular}

Speaking of Western countries' experience, the approach to academic support and student development generally appears to be more systematic: additional opportunities for academic support and student development outside the basic curricula provided both at the level of university and academic departments' administration. Most recently, teaching staff and administration have begun creating cross-functional and interdisciplinary groups to develop solutions for various groups of students. A common practice involves the creation of an entire cluster of units responsible for supporting students academically, psychologically, financially and socially. Universities hire specialists to help students with skill development, as well as organising entire programmes apart from the EP and available to all students regardless of their field of study. It is worth mentioning that some Russian universities are moving in the same direction and providing additional opportunities for improving quality of training of their students.

The practices identified in this review vary not only according to the stages of work, the target group of students and the level of implementation of the practices, but also by their complexity. The practices described above in some cases can be referred to as peculiar mega-practices (Honours colleges and academic excellence programmes, many examples of remedial courses in the USA). Such mega-practices include several merged practices, formed from a combination of additional courses, mentoring support from teachers and students, and distinctive teaching practices that we did not cover in this article.
The best case scenario is when the results and the implementation process of the listed practices and mega-practices are researched and evaluated by the university thus allowing to make necessary changes and adjustments to improve teaching and learning and student success.

\section{Conclusions for educational policy and management}

The concept of a responsible university means that students have all necessary educational opportunities. At the same time, the availability of such educational opportunities within the curriculum framework is not always sufficient; therefore, students should have support and development opportunities outside their degree-based EP. In order for Russian universities to take more responsibility regarding students, a deep and comprehensive analysis of students' data should be conducted. This should include an analysis of the school grades and national exams scores, individual achievements, and also should be supplemented (especially for the freshmen) with information about current academic performance, the socio-economic status, students' interests, aspirations and hobbies, as well as their learning styles and psychological profile. In order to provide best educational opportunities, the choice of practice, its content, structure and pace should be dictated by the characteristics of the students for whom this practice is created. 
The practices presented in this work can help universities address the quality of education, and academic diversity. The current situation, when universities are more likely to work with high achieving students, is more likely to lead to an increase in the academic diversity in the university and, accordingly, to an increase in the educational quality gap among students. Universities need to help their low-achieving students in order to reduce academic diversity.

In spite of that, Russian current practices demonstrated that low-achieving students tend to be left without sufficient attention from universities. Support and development practices for this group are found in literature and are mentioned by administrators much less often than practices for high-achieving students. This looks rather strange, considering that more than $17 \%$ of students who enrolled tuition-free and more than $30 \%$ tuition-paying students are admitted to Russian universities with an average USE score below 56 (out of 100), which is considered to be low quality level of admission ${ }^{25}$. Universities can expand existing practices of student support through thoughtful adaptation of the instruments described above.

In an interview, some administrators admitted that their university refuses to offer remedial courses due to their unpopularity and inefficiency. Some international universities also report the same negative experience, with low achieving students expressing no desire to use this service provided by universities [36, 37]. In this case, additional or alternative ways can be developed for involving such students, for example, through lowering the price of remedial courses and the use of other practices, for example, online technologies. An additional online support as part of the course on elementary statistics turned out to be quite effective [38].

What is quite obvious in our context is the possibility and even the need for a deeper use of the peer-effect. Apart from cases when senior students are involved as tutors and consultants by university, in Russia, such practices are often carried out by the students themselves either through student councils (communities), or on a completely informal basis. However, in this form, assistance can mainly be provided for students already quite well socialised in their environment. For those who do not adapt well to new conditions, such opportunities remain closed. Therefore, universities should consider the option of formalising and institutionalising forms of educational interaction between students with the increased involvement of senior students as mentors. This can both help low-achieving students, from the point of

${ }^{25}$ According to the monitoring of admissions quality for 2018. view of mastering the required skills, knowledge and competencies, socialisation in the university environment. Institutionalising educational interaction will also help high achieving students, providing them with deeper understanding of the issues related to their active life position. Moreover, the practices associated with the peer-effect, if properly organised, can present an effective instrument for reducing academic diversity with a positive effect for both successful and unsuccessful students. However, the formalisation process should not be reduced to establishing the superficial voluntary-compulsory nature of such relations, since this risks to reduce the positive effect of such practices to zero. The sincere mutual involvement of students is one of the key factors for successful student interaction.

The introduction of additional student support instruments should be accompanied by providing opportunities for the professional development of teachers. Working with high and low-achieving students requires different skills and mastery of teaching. At the same time, while a relatively large number of guidelines and manuals, and courses on working with gifted or low-achieving children exist for school-level teachers, teachers at Russian universities have limited access to support instruments.

Quality evaluation of the practice effectiveness is an essential additional element of comprehensive work with students under conditions of academic diversity. Such evaluation will allow administrators, researchers and teachers evaluate the adequacy of the resources they spend and identify the ways of improvement. The comprehensiveness of measures for dealing with academically diverse students should also be ensured by the involvement of both administrators and academic staff. Based on available student data, crossfunctional and sometimes interdisciplinary work on evaluating the effectiveness of current practices can serve as a way to provide the best educational opportunities outside the curricula for both the best students and those with academic difficulties.

In conclusion we should note that university policies in student support in the Russian context still remain a poorly investigated problem. For the further development of research in this field, it would be helpful to address how current federal policy affects university policy for student support; what incentives and obstacles it sets; how the institutionalization of new practices occurs, what practices are institutionalized, and what contributes to this; how student dropouts and university policies of supporting lowachieving students are connected, and how student support and development are reflected in university programs and strategies. Moreover, the technological 
development reveals new opportunities for universities to work with students, so the study of the effects and possibilities of using online technology and digitalization for comprehensive student support is becoming more relevant than ever.

\section{References}

1. Deil-Amen R. The «traditional» college student: A smaller and smaller minority and its implications for diversity and access institutions. Mapping Broad-Access Higher Education Conference at Stanford University, 2011, vol. 1, available at: http://cepa.stanford.edu/sites/default/files/2011 \%20Deil-Amen\%2011_11_11.pdf (accessed 04.06.2019). (In Eng.).

2. Marginson S. The worldwide trend to high participation higher education: dynamics of social stratification in inclusive systems. Higher Education. Dordrecht, Springer, 2016, vol. 72, No. 4, pp. 413-434. doi.org/10.1007/ s10734-016-0016-x. (In Eng.).

3. Vossensteyn J. J., Kottmann A., Jongbloed B. W. A., Kaiser F., Cremonini L., Stensaker B., Hovdhaugen E., Wollscheid S. Dropout and completion in higher education in Europe: main report. 2015. 104 p. doi. org/10.2766/826962. (In Eng.).

4. Kuh G. D., Kinzie J. L., Buckley J. A., Bridges B. K., Hayek J. C. What matters to student success: A review of the literature. NPEC, 2006. 156 p. (In Eng.).

5. White K. R. The Relation between Socioeconomic Status and Academic Achievement. Psychological Bulletin, 1982, vol. 91, No. 3, pp. 61-81. doi. org/10.1037//0033-2909.91.3.461. (In Eng.).

6. Arum R., Roksa J., Budig M. J. The romance of college attendance: Higher education stratification and mate selection. Research in Social Stratification and Mobility, 2008, vol. 26, No. 2, pp. 107-121. doi.org/10.1016/j. rssm.2008.02.003. (In Eng.).

7. Pascarella E. T., Terenzini P. T., Hibel J. Studentfaculty interactional settings and their relationship to predicted academic performance. The Journal of Higher Education, 1978, vol. 49, No. 5, pp. 450-463. doi.org/10.1080/00221546. 1978.11780395. (In Eng.).

8. Poldin O. V., Yudkevich M. M. Effecty soobucheniya v vysshem obrazovanii: obzor teoreticheskih I empiricheskih podhodov. [Peer-effects in higher education: a review of theoretical and empirical approaches]. Educational Studies. 2011, No. 4, pp. 106-123. doi: 10.17323/1814-9545-2011-4-106-123. (In Russ.).

9. Chang J. The interplay between collectivism and social support processes among Asian and Latino American college students. Asian American Journal of Psychology, 2015, vol. 6, No. 1, pp. 4-14. dx.doi.org/10.1037/a0035820. (In Eng.).

10. 1Stolle-McAllister K. The Case for Summer Bridge: Building Social and Cultural Capital for Talented Black STEM Students. Science Educator, 2011, vol. 20, No. 2, pp. 12-22. (In Eng.).

11. Salmun H., Buonaiuto F. The Catalyst Scholarship Program at Hunter College. A partnership among earth science, physics, computer science and mathematics. Journal of STEM Education: Innovations \& Research, 2016, vol. 17, No. 2, pp. 42-50. doi:10.1080/87567555.2011.627576. (In Eng.).
12. Garrett L., Davies C. Talented tertiary students: A largely 'forgotten' group within the tertiary sector? International Journal of Teaching and Learning in Higher Education, 2014, vol. 26, No. 1, pp. 78-89. (In Eng.).

13. Bettinger E. P., Long B. T. Addressing the needs of underprepared students in higher education does college remediation work? Journal of Human resources, 2009, vol. 44, No. 3, pp. 736-771. doi.org/10.3386/w11325. (In Eng.).

14. Bailey T., Jeong D. W., Cho S. W. Referral, enrollment, and completion in developmental education sequences in community colleges. Economics of Education Review, 2010, vol. 29, No. 2, pp. 255-270. doi.org/10.1016/j. econedurev.2009.09.002. (In Eng.).

15. Xu D. Assistance or obstacle? The impact of different levels of English developmental education on underprepared students in community colleges. Educational Researcher, 2016, vol. 45, No. 9, pp. 496-507. doi: 10.3102/0013189X16 683401. (In Eng.).

16. Woods C. S., Richard K., Park T., Tandberg D., Hu S., \& Jones T. B. Academic advising, remedial courses, and legislative mandates: An exploration of academic advising in Florida community colleges with optional developmental education. Innovative Higher Education, 2017, vol. 42, No. 4, pp. 289-303. doi.org/10.1007/s10755-016-9385-4. (In Eng.).

17. Rodgers K., Blunt S., Trible L. A real PLUSS: An intrusive advising program for underprepared STEM students. NACADA Journal, 2014, vol. 34, No. 1, pp. 35-42. doi. org/10.12930/nacada-13-002. (In Eng.).

18. Cholewa B., Schulthes G., Hull M. F., Bailey B. J., \& Brown J. Building on What Works: Supporting Underprepared Students through a Low-Cost Counseling Intervention. Journal of Student Affairs research and practice, 2017, vol. 54, No. 3, pp. 261-274. doi.org/10.1080/19496 591.2017.1331445. (In Eng.).

19. Buttram S. Beginning a Learning Community: Pilot Fall 2006. Journal of Developmental Education, 2016, vol. 40, No. 1, pp. 29-31. (In Eng.).

20. Xu D., Solanki S., McPartlan P., \& Sato B. EASEing Students Into College: The Impact of Multidimensional Support for Underprepared Students. Educational Researcher, 2018, vol. 47, No. 7, pp. 435-450. doi.org/10.3102/0013189X1 8778559. (In Eng.).

21. Tatro C. N., Hodson J. B. Partners in student success. New Directions for Higher Education, 2011, No. 153, pp. 25-34. doi.org/10.1002/he.423. (In Eng.).

22. Hughes A. N., Gibbons M. M., Mynatt B. Using narrative career counseling with the underprepared college student. The Career Development Quarterly, 2013, vol. 61, No. 1, pp. 40-49. doi. org/10.1002/j.2161-0045.2013.00034.x (In Eng.).

23. Mungal A., Cloete M. Preparing underprepared students for higher education and beyond: the development and implementation of an integrated project. Accounting Education, 2016, vol. 25, No. 3, pp. 203-222. doi: 10.1080/09 639284.2016.1157760. (In Eng.).

24. Grandstaff-Beckers G., Saal L. K., Cheek Jr E. Investigating treatment fidelity and social validity of a peermediated postsecondary reading intervention. Reading Psychology, 2013, vol. 34, No. 4, pp. 336-354. doi.org/10.108 0/02702711.2011.636477. (In Eng.). 
25. Severs E. Fostering Professional Growth: Models to Support Developmental Educators. Journal of Developmental Education, 2017, vol. 40, No. 3, pp. 29-31./doi/10.1002/cc.306/ full (In Eng.).

26. Budny D., Paul C. A., Newborg B. B. Impact of peer mentoring on freshmen engineering students. Journal of STEM Education: Innovations and Research, 2010, vol. 11, No. 5/6, pp. 9-24. doi: 10.1109/FIE.2006.322596. (In Eng.).

27. Morgan K. M., Northey E. E., Khalil M. K. The effect of near-peer tutoring on medical students' performance in anatomical and physiological sciences. Clinical Anatomy, 2017, vol. 30, No. 7, pp. 922-928. doi: 10.1002/ca.22954. (In Eng.).

28. Gunersel A. B., Simpson N. Improvement in Writing and Reviewing Skills with Calibrated Peer Review ${ }^{\mathrm{TM}}$. International Journal for the Scholarship of Teaching and Learning, 2009, vol. 3, No. 2, pp. 1-15. doi.org/10.20429/ ijsotl.2009.030215. (In Eng.).

29. Volkova M. A. Sistema sodeystviya lichnostno-professionalnomy razvitiyu studentov Politekhnicheskogo instituta Nacionalnogo issledovatelskogo universiteta $\mathrm{v}$ ramkah organizacii vneuchebnoy raboty [System of assistance to the personal and professional development of students of the Polytechnic Institute of the National Research University in the framework of the organization of extracurricular activities]. Innovative trends in the development of the education system, 2017, pp. 83-86. (In Russ.).

30. . Studencheskoye konstruktorskoye buro kak model innovacionnoy i nayuchnoy raboty molodegi v paradigme universitet 3.0 [Student design bureau as a model of innovative and research work of youth in the paradigm of a university 3.0]. Aktyalnyye voprosy ingenernogo obrazovaniya: soderganiye, tekhnologii, kachestvo. Materialy VIII Vserossiyskoy nauchno-metodicheskoy konferencii [Actual issues of engineering education: content, technology, quality. Materials of the VIII All-Russian Scientific and Methodical Conference], Kazan, 2018, pp. 17-22. (In Russ.).

31. Makhina T. Yu., Rygkova T. V., Tushkanov D. A., Chistyakova N. A. Otcenka tvorcheskogo potenciala studenta na primere olimpiady «Prakticheskaya stokhastika $-2013 » \mathrm{~V}$ REU im. G. V. Plekhanova [Evaluation of a student's creative potential on the example of the «Practical stochastic 2013» Olympiad at the Plekhanov Russian University of Economics]. News of the Plekhanov Russian University of Economics, 2014, No. 4, pp. 161-178. (In Russ.).

32. Sharova E. I. Obespecheniye kachestva vuzovskogo obrazovaniya: adaptaciya pervokursnikov (teoreticheskiye podhody k postanovke problemy) [Enshuring high quality of

Submitted on 27.06.2019 high school education: adaptation of first-year students]. The Bulletin of the Adyghe State University. Series «Pedagogy and Psychology», 2015, No. 1 (157), pp. 119-125. (In Russ.).

33. Grinshpon Ya. S., Ozerkin D. V. Dopolnitelnyye obrazovatelnyye usligi po matematike dlya stuentov mladshih kursov kak factor povysheniya uspevayemosty na fakultete [Additional educational services in mathematics for undergraduate students as a factor of improving academic performance at the faculty]. Sovremennoye obrazovaniye: praktiko-oriyentirovannyye tekhnologii podgotovki inzhenernykh kadrov. Materialy mezhdunarodnoy nauchno-metodicheskoy konferentsii [Modern education: practice-oriented technology training of engineering personnel. Materials of the international scientific-methodical conference], Tomsk, 2015, pp. 226-228. (In Russ.).

34. Lisichkina O. M. Formy raboty so slabo podgotovlennymi studentami [Forms of work with underprepared students]. Psychology and Pedagogy: Past, Present and Future, 2014, pp. 65-66. (In Russ.).

35. Trubcheninova I. A., Busygina A. V. Primeneniye tekhnologii adaptatsii pervokursnikov dlya povysheniya kachestva obrazovaniya na primere Tomskogo gosudarstvennogo universiteta sistem upravleniya i radioelektroniki [Application of adaptation of first-year students to improve the quality of education on the example of Tomsk State University of Control Systems and Radioelectronics]. Sovremennoye obrazovaniye: razvitiye tekhnologiy i soderzhaniya vysshego professional'nogo obrazovaniya kak usloviye povysheniya kachestva podgotovki vypusknikov [Modern education: the development of technologies and content of higher professional education as a condition for improving the quality of graduates]. 2017, pp. 89-90. (In Russ.).

36. Hodges R., White Jr W. G. Encouraging high-risk student participation in tutoring and supplemental instruction. Journal of Developmental Education, 2001, vol. 24, No. 3, pp. 2-9. (In Eng.).

37. Moore R., LeDee O. Supplemental instruction and the performance of developmental education students in an introductory biology course. Journal of College Reading and Learning, 2006, vol. 36, No. 2, pp. 9-20. doi.org/10.1080/107 90195.2006.10850184. (In Eng.).

38. Sargent C. S., Borthick A. F., Lederberg A. R., \& Haardörfer R. A low-maintenance approach to improving retention: Short on-line tutorials in elementary statistics. Journal of College Student Retention: Research, Theory \& Practice, 2013, Vol. 14, No. 4, pp. 549-566. doi.org/10.2190/ cs.14.4.g. (In Eng.).

\section{Accepted on 08.09.2019}

\section{Information about the authors:}

Farida R. Zagirova - Post-Graduate Student, National Research University Higher School of Economics, Analyst, Institute of Education, Laboratory for University Development; +7 (495) 772-95-90 (*22126); fzagirova@hse.ru.

Isak D. Froumin - Academic Supervisor, Institute of Education, National Research University Higher School of Economics; ifroumin@hse.ru. 